\title{
LIBRARY EXHIBITS
}

\author{
BY CLARK L. BECK, JR.
}

The year's first exhibit traced the development of music in America from I 640 to I 865. Manuscripts, books, musical scores, broadsides and newspapers recounted the transition in American musical tastes from the sacred hymns of the seventeenth century to the popular and patriotic songs of the Civil War. In an age of mass communication, it is difficult to envision a musical tradition based solely on printed text and live performance. However, as the exhibit demonstrated, pre-industrial America was far from a musical wasteland. The abundance of display material available in the Library's collection suggests that music was an integral part of American culture. Perhaps music was even more meaningful to our ancestors than it is to us, who think nothing of being exposed to an entire waking day of radio, television and phonograph emissions. At any rate, the musical repertoire of America's first two centuries provides an insight into the character of its founders, just as that of the I970's reflects the dynamism of contemporary society. Providing this insight was the primary function of the exhibit, a function amply fulfilled.

"The Dust Bin of History: American Presidential Losers, I 796I968," coincided with the recent general election. The exhibit concentrated on the unsuccessful candidates in American Presidential campaigns, and included those Presidents who were not always winners as well as those who never won an election and whose names faded into oblivion as soon as the returns were counted. Featured were authentic letters and documents, broadsides, books, pictures, campaign buttons, political cartoons, etc., on every Presidential loser from Thomas Jefferson to Hubert Humphrey. Outstanding display items included original campaign medals of Andrew Jackson and William Henry Harrison, a Whig campaign flag of 1844 , a vicious Democratic cartoon of 1864 depicting "a miscegenation ball" attended by Republican notables, an authentic I9I 2 photograph of Theodore Roosevelt campaigning in New Brunswick, a letter written by Wendell Willkie commenting on his I940 defeat and an optimistic note from House Speaker Sam Rayburn assessing Stevenson's chances for victory in 1956. Apart from an obvious topical 
appeal at election time, the exhibit served as a painless medium of instruction for many. Judging from the numbers of interested viewers and favorable comments, this was one of the most successful exhibits the Library has sponsored in recent years.

As with most minorities, concern over the plight of the American Indian has reached increasing proportions in recent years. This current preoccupation suggested the theme for the Library's current exhibit, in which several aspects of Indian culture and history are highlighted. Besides related manuscripts, broadsides, books and pictures, original artifacts of North and South American Indians are displayed. Following a topical arrangement, the exhibit portrays aboriginal Indian culture, initial encounters with the white man, Indian art and religion, missionary endeavors among the Indians, and white-Indian hostilities. Among the noteworthy items exhibited are seventeenth-century deeds for Indian land, including the original agreement to purchase the area upon which Rutgers University was ultimately built. Of special interest and beauty are a number of color folio plates depicting Indian chiefs, warriors and women done by Thomas McKenney and James Hall between I 836 and I 844 . 